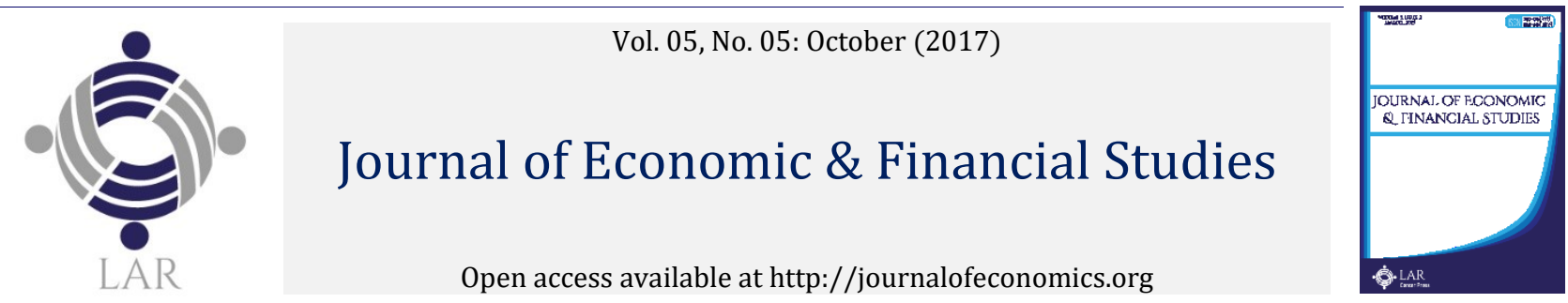

\title{
Recent monetary policy effects on Japanese macroeconomy
}

\author{
Yutaka Kurihara $\mathrm{a}^{*}$ \\ a Department of Economics, Aichi University, Japan. \\ ${ }^{*}$ Corresponding author's email address: kurihara@vega.aichi-u.ac.jp
}

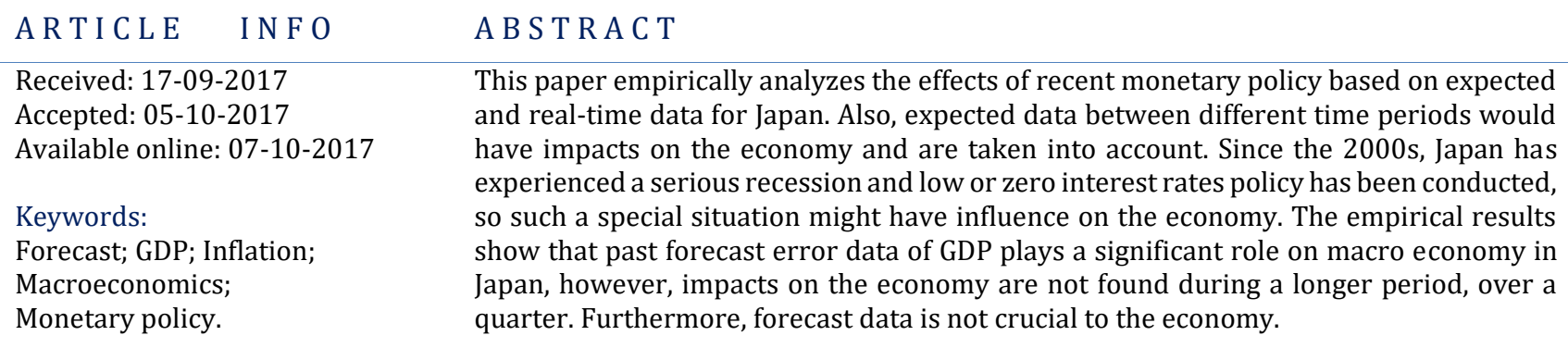

JEL Classification:

E4; E5.

(C) 2017 The Authors. This is an open access article under the terms of the Creative Commons Attribution License 4.0, which allows use, distribution and reproduction in any medium, provided the original work is properly cited.

DOI: http://dx.doi.org/10.18533/jefs.v5i05.296

ISSN 2379-9463(Print), ISSN 2379-9471(Online)

\section{Introduction}

This paper analyzes the effects of recent monetary policy based on expected and real-time data for Japan. Also, expected data changes are taken into account. There is some possibility that the differences between expected and real-time data and between expected data and the changed data would influence the economy. Since the 2000s, Japan has experienced serious deflation and recession, and, to combat this situation, low or zero interest rates policy has been conducted, so such a special situation might have influenced the economy. Traditional theory may not fit.

Japan has been in a severe economic situation and deflation since the so-called bubble economyburst at the beginning of the 1990s. In the latter part of the 1980s, Japan experienced a tremendous rise in land and stock prices called the bubble economy, however, the bubble burst. In 2001, the central Japanese bank, Bank of Japan (BOJ), raised the outstanding balance of the current account at the BOJ. Usually, central banks make interest rates move (i.e., rise, reduce, or stay) when conducting monetary policy; however, at that time, interest rates in Japan were already too low to boost the economy. There was no room to reduce interest rates (i.e., zero interest rate). Of course the basic discount rate and basic loan rate still exists, however, this monetary policy objective could be perceived as a change from holding a level of reserves at the BOJ to one that transfers funds into lending to combat deflation and to boost the economy. Under this quantitative easing policy, which began March 19, 2011, the BOJ started to purchase huge amounts of Japanese government bonds to arrive at its target level of current account balances held by financial institutions. This was called unconventionalmonetary policy, which was unprecedented in the world at that time. The policy continued to be in effect until July 14, 2006 when a bright sign appeared for the Japanese economy. However, after the subprime problems in 2007 and the Lehman shock in 2008, a huge amount of capital flowed into the Japanese financial markets despite the Japanese economy still not being in a good situation. The Japanese currency, yen, appreciated greatly against other currencies, which hit the Japanese economy hard. Japanese export was seriously damaged. On October 5, 2010, the BOJ introduced its comprehensive 
monetary easing policy to respond to the re-emergence of deflation. The BOJ's zero interest rate policy was effective again beginning in October 2010.

On April 4, 2013, the BOJ decided to conduct quantitative and qualitative monetary easing policy, which is a much more aggressive monetary policy. The BOJ decided to achieve the consumer price target of $2 \%$ for the year-to-year rate of change in consumer prices. Deflation was still considered as causing serious damage to the Japanese economy. The BOJ doubled the monetary base and the outstanding amounts of Japanese government bonds as well as exchange-traded funds (ETFs) in two years and more than doubled the maturity of Japanese government bond purchases (i.e., quality). Furthermore, on January 29, 2016, the BOJ decided to introduce quantitative and qualitative monetary easing (QQE) with a negative interest rate to achieve the price stability target of $2 \%$ at the earliest possible time. The BOJ applies a negative interest rate of minus $0.1 \%$ to current accounts that financial institutions hold at the bank. Minus interest rate policy is still in effect despite much discussion.

Roughly speaking, dividing into two periods from the 1990s in Japan, namely from 1990-2000 and from 2000-present. The reason why these two periods are selected were explained above. It would be possible and adequate to divide into more periods than two, but this paper uses quarterly data for empirical analysis, so two periods are applied in this paper.

\section{2. $\quad$ Related Studies}

This paper examines data differences caused by the time delay and the inappropriate, yet occasionally rational, data expectation. Two types of similar studies exist.

One type comes from market communication. Central bank communication with financial markets is sometimes important when central banks conduct their monetary policies. Schmidt and Nautz (2012) found that efficient and effective communication among financial markets with the policy authorities should ensure that financial markets understand the central banks' policies, especially how interest rates are linked to future output and inflation. Christensen and Rudebusch (2012) showed that decreases in the U.S. interest rate spreads reflect expectations of future low short-term interest rates, whereas decreases in the U.K. interest rate yields reflect reduced premiums of interest rates. Komain (2012) confirmed evidence of risk spillovers in the stock and foreign exchange markets in emerging economies. Leon and Williams (2012) used a matched-sample test of before- and after-intervention events in foreign exchange markets and showed that interventions were effective. For the Japanese context, Kurihara (2011) examined the impact of news announcements by the BOJ on interest rates using daily data.

The other type of study is coming from data changes or updates. Just before the first initial data are released and again when confirmation data are released, economists and private economic institutions expect each report. When they are published, market participants, sometimes computers, see them and do transactions, invest, and sometimes speculate using the published data. Markets sometimes fluctuate owing to such participants' transactions. Also, they sometimes make use of economic data disparities on purpose. However, sometimes a large variety of expectations and the transactions that are based on such expectations do not stabilize markets. Recent developments in ICT may accelerate turmoil (i.e., economic stability). Mankiw and Shapiro (1986) showed that data revisions cause uncertainty because of the reliability of economic data in real time. Zarnowitz and Lambros (1987) indicated that the relationship between survey-based dispersion and macroeconomic uncertainty depends on the assumption that forecasters in markets have stronger effects during times of greater economic turmoil. Fair and Shiller (1990) found that the quality of economic forecasts relies strongly on the volatility of the economy. Belke and Klose (2011) found that the use of real-time instead of ex post data leads to a higher estimated output gap and inflation gap. Kalckreuth and Wolff (2011) showed that discretionary fiscal policy is influenced by measurements of data error. Neri and Ropele (2011) found that the estimated policy rule becomes more inertial and less aggressive for the case of inflation rates. Giannone, Henry, Lalik, and Modugno (2012) indicated that data revisions cause the economic instability that surrounds key macroeconomic ratios. Laurent and Andrey (2014) showed that forecast accuracy of data improves when the probability forecasts of both the coincident indicators model and the yield curve model are combined. Beradi and Duffy (2015) showed that the method of real-time parameterized expectations learning gives a plausible alternative way to use the real-time adaptive learning dynamics model. Leopoldo and Guilermo (2015) found that there is no reason to accept the interpretation that forecast errors have unfortunate systematic effects on fiscal pro-cyclically. Baetje and Friedrici (2016) showed that disagreement is significantly linked with data uncertainty. Cimadomo (2012) found that forecast errors for the government structural balance and the output gap play important roles in explaining the differences between estimates based on ex ante and ex post data. Also, Cimadomo (2016) indicated that fiscal data revisions are large, and initial releases are biased estimates of final ones.

Some studies have examined data dispersions including GDP; however, there are not enough of these in spite of their importance. In regards to macroeconomic situations, inflation should be taken into account. Also, few studies have examined the Japanese case. Using macroeconomic data, this study focuses on predicted real output and inflation rates. Moreover, recent Japanese unconventional monetary policy conducted from the early 2000s. 


\section{Theoretical view}

This paper's analysis is based on the research of Romer and Romer (2000). As Cloyne and Hürtgen (2016) indicated, this paper is characterized by three things: monetary policy instruments, interest rates, and other macroeconomic variables are determined simultaneously; policymakers are likely to react to expected future economic conditions as well as current and past information; and policymakers base their decisions on real-time data instead of ex post data often used in other empirical studies. These aspects still have not been discussed in depth.

More concretely, this paper hypothesizes that interest rates are determined by GDP and inflation. For both explanation variables, GDP and inflation, differences between real-time data and the one and two quarter ahead forecasts of real GDP growth and inflation rate and revisions in the forecasts relative to the previous round of forecasts of real GDP growth and inflation rate. Interest rate differences between short-term money market rates and the basic discount rate/basic loan rates are regressed by the variables listed in equations (1) and (2).

\section{Empirical methods and analyses}

\subsection{Methods}

The BOJ sets a basic discount rate and a basic loan rate intended as policy target rate, so it is not necessary to construct the implied policy target rate.

The regression equation is

$$
\Delta \mathrm{i}_{\mathrm{q}}=\alpha+\beta \mathrm{i}_{\mathrm{t}-1}+\sum_{j=-1}^{2} \gamma \mathrm{jyq}, \mathrm{j}+\sum_{j=-1}^{2} \delta \mathrm{j} \pi \mathrm{q}, \mathrm{j}+\sum_{j=-1}^{2} \zeta \mathrm{j}(\mathrm{yq}, \mathrm{j}-\mathrm{yq}-1, \mathrm{j})+\sum_{j=-1}^{2} \eta \mathrm{j}(\pi \mathrm{q}, \mathrm{j}-\pi q-1, j)
$$

where the dependent variable is measured at a meeting-by-meeting frequency as indicated by subscript q. For the forecast and real-time data, the subscript $j$ denotes the quarter of this relative to the meeting date. The change in the intended policy target around the policy decision on the one and two quarter ahead forecasts of real GDP growth $y q, j$ and inflation $\pi q, j$ as well as the real-time back data of the previous period and the forecast for the current period. The equation also includes revisions in the forecasts relative to the previous round of forecasts $(y q, j-y q-1, j)$ and $(\pi q, j-\pi q-1, j)$.

Robust estimation is also used for estimation along with the ordinary least squares (OLS). Robust estimation is unlike maximum likelihood estimation. OLS estimates for regression are sensitive to the observations that do not follow the pattern of the other observations. This is not a problem if the outlier is simply an extreme observation from the tail of a normal distribution; however, if the outlier is from non-normal measurement error or some other violation of standard OLS, it compromises the validity of the regression results if a non-robust regression method is employed.

All of the real data are from IMF (IFS) and forecast data are from Economic Outlook (OECD). The sample period is divided into 1990Q1-1999Q4 and 2000Q1-2016Q4. More aggressive monetary expansion policy is conducted during the latter.

\subsection{Results}

The results are provided in Table 1 . Result suggest that not all of the empirical analyses are robust, but they show that past forecast error data of GDP plays a significant role on the macro economy in Japan. With a longer period, over a quarter, impacts on the economy are not found. Also, forecast data is not crucial.

Table 1: Empirical results

\begin{tabular}{lrrrr}
\hline Sample period & \multicolumn{2}{c}{ 1990Q1-1999Q4 } & \multicolumn{2}{c}{2000 Q1-2016Q2 } \\
\hline Empirical Method & Least Squared & $\begin{array}{r}\text { Robust } \\
\text { Estimation }\end{array}$ & Least Squared & $\begin{array}{r}\text { Robust } \\
\text { Estimation }\end{array}$ \\
\hline C & $-0.0278^{*}$ & $-0.0143^{* * *}$ & $-0.0481^{* *}$ & 0.0006 \\
& $(-1.6789)$ & $(-5.1395)$ & $(-2.6208)$ & $(0.3766)$ \\
Interest rate - target rate & $0.9200^{* * *}$ & $0.9735^{* * *}$ & $0.7971^{* * *}$ & $1.0029^{* * *}$ \\
& $(26.2603)$ & $(164.5770)$ & $(13.5274)$ & $(193.9142)$ \\
EGDP(+1) - GDP(+1) & $0.0209^{* *}$ & 0.0006 & 0.0052 & $8.26 \mathrm{E}-05$ \\
& $(2.1839)$ & $(0.4279)$ & $(0.9203)$ & $(0.1650)$ \\
EGDP - GDP & $-0.0177^{*}$ & $-0.0022^{*}$ & $-0.0011^{* *}$ & -0.0004 \\
& $(-1.8736)$ & $(-1.8016)$ & $(-2.0509)$ & $(-0.8861)$ \\
EGDP(-1)-GDP(-1) & $0.0192^{*}$ & $0.0051^{* * *}$ & $0.0209^{* * *}$ & 0.0002 \\
& $(1.7622)$ & $(2.7850)$ & $(3.2946)$ & $(0.4275)$ \\
EGDP(-2) - GDP(-2) & -0.0085 & -0.0010 & -0.0030 & -0.0001 \\
& $(-0.8474)$ & $(-1.5016)$ & $(-0.5116)$ & $(-0.3688)$ \\
EGDP(+1) - EGDP & -0.0001 & 0.0006 & 0.0008 & $-0.0003^{*}$ \\
& $(-0.0297)$ & $(0.8778)$ & $(0.3997)$ & $(-1.9290)$ \\
EGDP - EGDP(-1) & 0.0023 & -0.0010 & $-4.40 \mathrm{E}-05$ & $-9.86 \mathrm{E}-06$
\end{tabular}




\begin{tabular}{|c|c|c|c|c|}
\hline & $(0.5057)$ & $(-1.5016)$ & $(-0.1179)$ & $(-0.4580)$ \\
\hline \multirow[t]{2}{*}{$\operatorname{EGDP}(-1)-\operatorname{EGDP}(-2)$} & $-0.0088^{* *}$ & -0.0003 & -0.0293 & -0.0001 \\
\hline & $(-2.3868)$ & $(-0.4886)$ & $(-1.4818)$ & $(-0.7008)$ \\
\hline \multirow{2}{*}{ Einflation $(+1)$ - inflation $(+1)$} & 0.0176 & -0.0084 & 0.0198 & -0.0041 \\
\hline & $(0.3551)$ & $(-1.0032)$ & $(0.6821)$ & $(-1.6058)$ \\
\hline \multirow[t]{2}{*}{ Einflation - inflation } & $0.14470^{* *}$ & -0.0077 & -0.0284 & -0.0050 \\
\hline & $(-.2 .3420)$ & $(-0.7390)$ & $(-0.7753)$ & $(-1.551 c$ \\
\hline \multirow[t]{2}{*}{ Einflation $(-1)$ - inflation $(-1)$} & 0.1119 & 0.0159 & 0.0155 & -0.0004 \\
\hline & $(1.4596)$ & $(1.2342)$ & $(0.3480)$ & $(-0.112$ \\
\hline \multirow[t]{2}{*}{ Einflation $(-2)$ - inflation $(-2)$} & 0.0105 & $-0.0208^{*}$ & -0.0067 & -0.0006 \\
\hline & $(0.1554)$ & $(-1.8103)$ & $(-0.1673)$ & $(-0.1828)$ \\
\hline \multirow[t]{2}{*}{ Einflation $(+1)$ - Enflation } & 0.0153 & 0.0029 & 0.0024 & -0.0033 \\
\hline & $(0.3472)$ & $(0.3918)$ & $(0.0971)$ & $(-1.498)$ \\
\hline \multirow[t]{2}{*}{ Einflation - Einflation $(-1)$} & -0.0575 & -0.0065 & -0.0256 & -0.0004 \\
\hline & $(-1.3030)$ & $(-0.8722)$ & $(-1.0168)$ & $(-0.222)$ \\
\hline \multirow[t]{2}{*}{ Einflation $(-1)$ - Einflation $(-2)$} & 0.0252 & $0.0170^{* *}$ & 0.0134 & 0.0010 \\
\hline & $(0.5642)$ & $(2.2594)$ & $(0.5195)$ & $(0.4391$ \\
\hline Adj.R2 & 0.9166 & & 0.7623 & \\
\hline Adj. Rw2 & & 0.9969 & & 0.99 \\
\hline F-statistic & 79.4329 & & 15.3320 & \\
\hline Prob (F-statistic) & 0.0000 & & 0.0000 & \\
\hline Rn.2 statistic & & 46960.49 & & 43887.35 \\
\hline Prob (Rn.2 statistic) & & 0.000 & & 0.0000 \\
\hline D.W. & 2.3552 & & 2.5741 & \\
\hline Schwarz criterion & -0.2853 & 330.4852 & -1.9019 & 213.6956 \\
\hline
\end{tabular}

Note. Parentheses are t-statistics (LS) and z-statistics (Robust estimation). +++ denotes significant at 1\%, ** denotes significant at $5 \%$, and ${ }^{*}$ denotes significant at $10 \%$.

The interpretation is difficult. Monetary policy, namely money expansion, is surely related with boosting the economy. On the other hand, the relationship between monetary policy and inflation is not found. The Japanese economy has been struggling to combat deflation and authorities have attempted to overcome the situation, but the exit of such policy has not been found yet.

\section{Conclusions}

This paper empirically analyzed the effects of recent monetary policy from the 1990s based on expected and real-time data for Japan. Also, changes of expected data are taken into account. Since the 2000s, Japan has experienced a serious recession and low or zero interest rates policy has been conducted. Unprecedented monetary expansion has been conducted. The empirical results show that monetary policies have some effects to boost the economy for the periods of 1990s and of 2000s. Also, past forecast error data of GDP plays a significant role on macro economy in Japan. However, when examining a longer period, over a quarter, impacts on the economy are not found. The effects seem to disappear quickly. On the other hand, overcoming deflation has been and is still a serious problem prevailing Japan. Finally, forecast data does not play important roles for Japanese economy.

There is some room for this study. The sample limitation is one serious problem. This unprecedented policy was first conducted recently, so the number of the sample is not a lot. One solution is to use daily or monthly data, but the variable instead of output cannot found easily. Also, the distinction between zero or low interest rate policy and quantitative easing should be considered. However, if doing so, the number of the sample should decrease. Finally, using other variables along with inflation and output would be necessary. For example, exchange rates or stock prices would be important to examine the economy. There is some possibility that the reason of inflation should be examined carefully.

Recently, other countries have introduced such unprecedented monetary policy. Accumulation of research, examination, and comparison with these studies would be necessary. Further study is expected in the future.

Acknowledgement: This work was supported by JSPS KAKENHI Grant Number 15H03366. 


\section{References}

Baetje, F., \& Friedrici, K., (2010). Does cross-sectional forecast dispersion proxy for macroeconomic uncertainty? New empirical evidence. Economic Letters, 143: 38-43. doi:10.1016/j.econlet.2016.03.014

Belke, A., \& Klose, J., (2011). Does the ECB rely on a Taylor rule during the financial crisis? Comparing ex-post and real time data with real time forecasts. Economic Analysis and Policy, 41(2): 147-171.

Beradi, M., \& Duffy, J., (2015). Real-time, adaptive learning via parameterized expectations. Macroeconomic Dynamics, 19(2): 245-69.

Christensen, J. H. E., \& Rudebusch, G. D., (2012). The response of interest rates to U.S. and U.K. quantitative easing. The Economic Journal, 122: 385-414.

Cimadomo, J., (2012). Fiscal policy in real time. Journal of Economics, 114(2): 440-465.

Cimadomo, J., (2016). Real-time data and fiscal policy analysis: A survey of the literature. Journal of Economic Surveys, 30(2): 302-326.

Cloyne, J., \& Hürtgen, P., (2016). The macroeconomic effects of monetary policy: A new measure for the United Kingdom. American Economic Journal: Macroeconomics, 8(4): 75-102. doi:10.1257/mac.20150093

Fair, R. C., \& Shiller, R. J., (1990). Comparing information in forecasts from econometric models. American Economic Review, 80(3): 375-89.

Giannone, D., Henry, J., Lalik, M., \& Modugno, M., (2012). An area-wide real-time database for the Euro area. The Review of Economics and Statistics, 94(4): 1000-1013.

Kalckreuth, U., \& Wolff, G. B., (2011). Identifying discretionary fiscal policy reactions with real-time data. Journal of Money, Credit and Banking, 43(6): 1271-1285.

Komain, J., (2012). Linkages between Thai stock and foreign exchange markets under the floating regime. Journal of Financial Economic Policy, 4(4): 305-319.

Kurihara, Y., (2011). The relationship between exchange rate and stock prices during the quantitative easing policy in Japan. International Journal of Business, 11(4): 375-386.

Laurent, P., \& Andrey, V., (2014). Forecasting combination for U.S. recessions with real-time data. North American Journal of Economics and Finance, 28:138-48.

Leon, H., \& Williams, O. H., (2012). Effectiveness of intervention in a small emerging market: An event study approach. Applied Financial Economics, 22: 1811-1814.

Leopoldo, A., \& Guilermo, V., (2015). Fiscal procyclically and output forecast errors. Journal of International Money and Finance, 55:193-204.

Mankiw, N. G., \& Shapiro, M. D., (1986). News and noise: An analysis of GDP revision. Survey of Current Business, 66:20-25.

Neri, S., \& Ropele, T., (2011). Imperfect information, real-time data and monetary policy in the Euro area, Economic Journal, 122: 651-674.

Romer, D. C., \& Romer, D. H., (2000). Federal reserve information and the behaviour of interest rates. American Economic Review, 90:429-457.

Schmidt, S., \& Nautz, D., (2012). Central bank communication and the perception of monetary policy by financial market experts. Journal of Money, Credit, and Banking, 44(2-3): 323-340. doi:10.1.1.222.292\&rep

Zarnowitz, V., \& Lambros, L. A., (1987). Consensus and uncertainty in economic prediction. Journal of Political Economy, 95(3): 591-620. 